\title{
KERUGIAN EKOLOGIS AKIBAT TINDAK PIDANA KORUPSI
}

Oleh:

\author{
Joey Josua Pamungkas Pattiwael \\ Email: josuapamungkas45@gmail.com \\ Fakultas Hukum Universitas Airlangga Surabaya
}

\begin{abstract}
Abstrak
Tindak Pidana Korupsi di sektor sumber daya alam tidak hanya merugikan finansial negara saja yang dapat dihitung dari APBN, melainkan berdampak luas pula pada kerugian ekologis yang menimbulkan dampak terhadap manusia, bentang alam dan keanekaragaman hayati yang ada di dalamnya. Permasalahan yang akan dianalisa dalam Jurnal ini adalah Apakah kerugian lingkungan dapat dimaknai sebagai kerugian keuangan negara yang ada didalam Undang-undang tindak pidana korupsi dan Bagaimana pembuktian kerugian lingkungan demi pengembalian aset tindak pidana korupsi yang merupakan kerugian ekologis. Metode penelitian yang digunakan adalah penelitian hukum, Penelitian hukum dilakukan untuk memecahkan isu hukum yang di hadapi. Demi memperoleh jawaban atas isu hukum dalam penelitian ini penulis memakai pendekatan konseptual, pendekatan kasus, dan pendekatan Undang-undang. Hasil dari penelitian ini adalah kerugian ekologis yang timbul akibat tindak pidana korupsi sebagai kerugian keuangan negara, karena pemahaman yang telah di bangun tentang perluasan makna kerugian keuangan negara melalui tiga metode penafsiran yaitu sistematis, historis, dan ekstensif. Dalam hal pembuktian adanya kerusakan atau pencemaran lingkungan dapat di hadirkan ahli dalam bidang tersebut yang ada dalam Permen LH 7 Tahun 2014 untuk menghitung kerugian lingkungan yang ditimbulkan akibat penerbitan ijin tambang secara melawan hukum.
\end{abstract}

Kata Kunci: Kerugian Ekologis, Kerugian Keuangan Negara, Tindak Pidana Korupsi

\begin{abstract}
Abstrak
Corruption in the natural resources sector is not only detrimental to the state's finances, which can be calculated from the APBN, but also has a broad impact on ecological losses that have an impact on humans, landscapes and biodiversity in it. The problems that will be answered in this journal are whether environmental losses can be categorized as state financial losses that are in the corruption law and how to prove environmental losses for the return of assets of criminal acts of corruption which are ecological losses. The research method used is legal research. Legal research is carried out to solve legal issues at hand. In order to obtain answers to legal issues in this study, the authors use a conceptual approach, a case approach, and a statute approach. The results of this study are 1) ecological losses arising from criminal acts of corruption as losses to state finances, due to the understanding that has been built on the expansion of the meaning of state financial losses through three methods of interpretation, namely systematic, historical, and extensive or environmental pollution can be presented by experts in the field in the Minister of Environment and Forestry Regulation 7/2014 to calculate environmental losses caused by the illegal issuance of mining permits.
\end{abstract}

Keywords: Criminal Corruption, Ecological Loss, State Financial Loss

JURNAL RECHTENS, Vol. 10, No. 1, Juni 2021 


\section{PENDAHULUAN}

\subsection{Latar Belakang}

Umat manusia memiliki relasi yang saling membutuhkan dengan lingkungannya. Ruang geraknya berdampak pula pada lingkungannya sama halnya dengan itu, manusia pun dipengaruhi dengan lingkungannya. Hubungan saling terikat tersebut dimiliki oleh manusia sebagai kelompok maupun sebagai individu atau lingkungan alam dan masyarakatnnya. ${ }^{1}$ Asas-asas tentang sumber daya alam di bangsa Indonesia dituangkan dan diatur dalam pasal 33 Undang-Undang Dasar Negara Republik Indonesia Tahun 1945. Asas-asas tersebut yaitu: ${ }^{2}$

a. Asas kekeluargaan (Ayat 1): sumber daya alam yang terdapat pada bumi Indonesia adalah kepunyaan seluruh keluarga besar masyarakat Indonesia dan harus diberdayakan untuk seluruh warga Indonesia;

b. Asas dikuasai oleh Negara (Ayat 2): sumber daya alam yang ada pada bumi Indonesia dikelola dan dikuasai oleh negara, dimanfaatkan, dipelihara, di-berdayakan untuk kepentingan dan kesejahtraan seluruh rakyat Indonesia dan bukan

1 Daud Silalahi, Kristianto. Hukum Lingkungan dalam perkembangan di Indonesia, CV Keni Medi, Bandung, 2015, hlm. 10

2 Marsel Selamat, Hukum Sumber Daya Alam Indonesia, Satara Press, Malang, 2018, hlm. 9 untuk kepentingan indiviu maupun kelompok tertentu;

c. Asas manfaat (Ayat 3): pemanfaat atau pengelolaan sumber daya alam diperuntukan bagi kesejahteraan dan ke-pentingan seluruh warga bangsa Indonesia;

d. Asas efisiensi dan berkeadilan (Ayat 4): pemanfaatan sumber daya alam harus menghindari upaya eksploitasi terhadap sumber daya alam. Sumber daya alam harus digunakan secara bijaksana bagi kepentingan seluhur masyrakat Indonesia di masakini maupun yang akan datang.

e. Asas berkelanjutan (Ayat 4): sumber daya alam dijaga dan pelihara untuk kelestarian agar dapat di nikmati generasi selanjutnya;

f. Asas kemandirian (Ayat 4): pemberdayaan sumber daya alam harus dengan kemampuan indonesia sendiri;

g. Asas berwawasan lingkungan (Ayat 4): pemanfaatan sumber daya alam memperhatikan kelestarian lingkungan dan terpeliharanya ketersediaan sumber daya alam;

h. Asas keseimbangan (Ayat 4): pengelolaan sumber daya alam harus dengan menjaga kelestarian lingkungan dan terjaganya ketersediaan sumber daya alam;

i. Asas kebersamaan (Ayat 4): pengelolaan sumber daya alam harus menggunakaan konsep usaha bersama, yang berarti 
setiap individu memiliki peluang yang sama, sehingga terjadi saling ketergantungan antara rakyat, negara dan usaha swasta agar menjauhkan monopoli.

Indonesia sendiri memiliki kekayaan alam yang sangat melimpah ruah namun Kekayaan alam Indonesia yang begitu potensial dapat menjadi musibah atau berkat tergantung dari bagaimana pengelolaannya. Apakah pengelolaan tersebut berdasarkan atas prinsip-prinsip reidistribusi sumber daya alam yang berkeadilan, berpihak kepada kepentingan kemaslahatan, berasas pada pembangunan berkerlanjutan dan untuk sebagian besar kesejahteraan rakyat Indonesia. Sumber daya alam yang melimpah dapat menjadi musibah jika kompetensi dan integritas tidak dimiliki untuk mengelolanya. Pada saat ini, terjadi deforestasi besar-besaran tanpa kendali. Kerusakan hutan alam terjadi di seluruh wilayah. Permasalahan ini mempercepat lajunya deforsetasi sehingga menyebabkan luas hutan Indonesia berkurang sangat tajam. Bahayanya, pengelolaan dan penguasaanya hanya dikuasai oleh segelintir orang saja. Akibat yang timbul juga sangat serius, yaitu hilang dan hancurnya keanekaragaman hayati serta makin menurun- nya kualitas hutan bagi kepentingan lingkungan hidup maupun masyarakat. ${ }^{3}$

Adanya dugaan kuat, dimana sebagian besar izin pengelolaan dan penguasaan sumber daya alam hari-hari ini dilakukan dengan cara-cara yang diduga melawan hukum. KPK mencatat sedikitnya ada enam cara, antara lain praktik penyuapan, konflik kepentingan, penyalahgunaan wewenang penyelenggara negara pelaku usaha, serta ketidakpatuhan dalam melaksanakan kewajiban, gratifikasi, manipulasi data dan informasi. $^{4}$

Pemberian izin di sektor sumber daya alam senantiasa berkaitan dengan high cost politic dalam pemilihan kepala daerah. Salah satu hasil studi KPK mengkonfimasi, pemberian izin di sektor sumberdaya alam sangat rentan karena ada indikasi kuat kerap terjadi penyalahgunaan kewenangan, khususnya oleh pertahanan yang kembali mengikuti pemilihan kepala daerah. Selain itu, daerah tidak mempunyai data base dan perkiraan potensi kekayaan sumber daya alam yang dimilikinya serta memiliki "kelemahan" dalam melakukan bargaining guna mengoptimalisasi kepentingan daerah. Politik dinasti dan politik kartel, biasanya berhubungan dengan penyelengaraan negara yang mempunyai kewenangan di

\footnotetext{
${ }^{3}$ Bambabang Widjojanto Dkk, Penguasaan Sumber Daya Alam, Intrans Institute, 2017, hlm 9 ${ }^{4}$ https://m.tempo.com/read/news/2016/02/22/090747 097/kpk-temuan-enam-indikasi-tindak-pidana-disektor-energi.
} 
sektor sumber daya alam yang melibatkan orang pusat dan daerah. Unsur penegakan hukum dan aparat kohersif lainnya, kerap terjebak, potensial menjadi "centeng", messenger dan representatif kepentingan dari korporasi dan kekuasaan. ${ }^{5}$ Salah satu contoh kasus yang menarik adalah (Putusan Nomor 2633 K/Pid.Sus/2018) NA mantan gubernur Sulawesi Utara terjerat kasus korupsi yang di tangani oleh KPK, dikarenakan memberikan izin eksplorasi pada dua kabupaten, yaitu buton dan bombana. Karena situasi tersebut, NA dijatuhi pidana kurungan selama 18 tahun. Karena terbitnya izin pertambangan itu terdakwa mendapat keuntungan berupa uang sebanyak 2.781.000.000.000,00. Hal yang mengejutkan dan tidak biasa adalah jaksa penuntun umum KPK memasukan kerugian ekologis akibat dari kegiatan PT AHB sebagai kerugian negara sebesar 2.728.745.136.000,00 Langkah yang dilakukan KPK memasukan kerugian ekologis sebagai kerugian negara patut diberipujian dan menjadi topik yang baik untuk penulis analisa secara komperhensif dimana kalo kita berbicara korupsi jurusan keuangan negara sendiri ada dalam Pasal 2 dan 3 UU Tipikor dalam tataran praktekpun penafsirannya masih sering di perdebatkan sehingga berdampak

\footnotetext{
${ }^{5}$ Bambabang Widjojanto Dkk, Op.Cit, hlm 26
}

juga pada penanganan kasus tindak pidana korupsi. $^{6}$

Dalam perkembangannya, para penegak hukum pada saat ini merasa penting untuk memperhitungkan kerugiaan ekologis sebagai kerugian negara ini menjadi satu langkah progresif dimana sangat beralasan penuntut umum memasukkan kerugian lingkungan sebagai kerugian negara dalam kasus diatas.

\subsection{Rumusan Masalah}

Memperhatikan uraian sebagaimana diatas, maka permasalahan dalam penelitian ini dapat dirumuskan: Apakah kerugian lingkungan dapat dikategorikan sebagai kerugian keuangan negara yang ada didalam Undang-undang tindak pidana korupsi? Dan Bagaimana pembuktian kerugian lingkungan demi pengembalian aset tindak pidana korupsi yang merupakan kerugian ekologis?

\section{METODE PENELITIAN}

Tipe penelitian yang digunakan memakai tipe penelitian hukum. Legal research digunakan sebagai upaya menganalisa persoalan hukum yang di hadapi. Pada saat inilah harus dimiliki kapasitas untuk mencari penyelesaian dari persoalan hukum, dengan menggunakan legal

${ }^{6}$ Franky Butar Butar (Dkk), Mungkinkah Kerugian Lingkungan Akibat Pertambangan dapat Dikategorikan sebagai Tindak Pidana Korupsi, Prosiding Tpp XXVIII Perhapi, 2019, hlm 3 
reasoning, menganalisa persoalan yang di hadapi setelah itu diupayakan dapat menyelesaikan persoalan tersebut. Legal research adalah penelitian yang bertujuan mencari kebenaran koherensi, kegiatan ini berdasar pada tolak ukur yang berupa moral. Norma yang merupakan acuan perbuatan yang berlandaskan prinsip hukum berdasar pada moral. Peraturan hukum haruslah memiliki koherensi dengan norma hukum dan norma hukum koheren dengan prinsip hukum. ${ }^{7}$

Pendekatan yang digunakan dalam penelitian ini adalah pendekatan Undangundang (statute approach) dan peraturan yang terkait pada persoalan hukum yang tengah dihadapi. Pendekatan konseptual (conceptual approach) berangkat dari nilainilai dan doktrin-doktrin yang bertumbug dalam ilmu hukum. Pendekatan kasus (case approach) pendekatan ini dilakukan melalui menganalisa kasus-kasus yang terkait dengan isu yang dibahas dan kasus tersebut adalah kasus yang sudah diputusan Pengadilan dan sudah memikik kekuatan hukum tetap. ${ }^{8}$

\footnotetext{
7 Peter Mahmud Marzuki, Penelitian Hukum, Peredanamedia Group, Jakarta, 2005, hlm 64
}

${ }^{8}$ ibid Hal 133-135

\section{HASIL DAN PEMBAHASAN}

\subsection{Perluasan Makna Kerugian}

Keuangan Negara Meliputi Kerugian

\section{Ekologis}

Pada kenyataanya pasal 2 ayat (1) dan pasal 3 Undang-Undang tindak pidana Korupsi yang memuat unsur "merugikan keuangan negara" sering menimbulkan permasalahan dalam tataran pemaknaan antara tiap-tiap regulasipun memiliki pemaknaan yang berbeda ada yang menggunakan istilah "kerugian negara" ada yang menggunakan "kerugian keuangan negara atau perekonomian negara". Dalam tataran akademisi pun masih menjadi sesuatu yang di perdebatkan terkait pemaknaan kerugian keuangan negara.

Mengenai kerugian keuangan negara dapat dilihat dalam beberapa regulasi antara lain Undang-Undang Republik Indonesia Nomor 20 Tahun 2001 Tentang Perubahan Atas Undang-Undang Nomor 31 Tahun 1999 Tentang Pemberantasan Tindak Pidana Korupsi: Penjelasan pasal 32 ayat 1 Undang-undang Nomor 31 Tahun 1999 tentang Pemberantasan Tindak Pidana Korupsi, "Yang dimaksud dengan "secara nyata telah ada kerugian keuangan negara" adalah kerugian yang sudah dapat dihitung jumlahnya berdasarkan hasil temuan instansi yang berwenang atau akuntan publik yang ditunjuk" 
Pada unsur ini adalah ditempatkan objek tindak pidana pasal 2 dan pasal 3 . Objeknya adalah keuangan negaran dan perekonomian negara, sama halnya pada objek tindak pidana memperkaya diri dengan melawan hukum dalam pasal $2 .{ }^{9}$

Pasal 2 dan pasal 3 Undang-undang Tipikor mengandung kalimat "yang dapat merugikan keuangan negara atau perekonomian negara". Unsur tersebut adalah menjadi hal yang esensial karena menjadi dasar untuk menentukan apakah pelaku korupsi dapat dipidana atau tidak. Ketika semua unsur dalam pasal diatas terpenuhi maka pelaku dapat dijatuhi pidana maupun uang pengganti. Namum jika salah satu unsur dari pasal diatas tidak terpenuhi maka berakibat bebasnya pelaku korupsi dari penjatuhan hukum (baik dihentikan penyidik maupun dibebaskan oleh hakim pengadi-lan). Beberapa perkara korupsi yang dipengang kejaksaan terbukti pengadaan access fee Sisminbakum pada kementrian hukum dan HAM, pengadaan kapal tengker pertamina (VLCC), dan korupsi di PT. Texmaco dihentikan penyidikannya (SP3) disebabkan tidak terbuktinya ada unsur merugikan Negara. Walaupun banyak pelaku korupsi yang telah dijerat Undangundang Tipikor kemudian dimasukan dalam tahanan, dimana terbukti merugikan keuangan negara, meskipun demikian fakta

\footnotetext{
9 Adami Chazawi, Hukum Pidana Korupsi di Indonesia, Rajawali Pers, 2017, hlm 71
}

dilapangan menggambarkan penerapan unsur "merugikan keuangan negara" dalam Undang-undang Tipikor, ternyata sering me-nimbulkan persoalan. ${ }^{10}$

Pasal 1 angka 15 Undang-undang Nomor 15 Tahun 2006 tentang "Badan Pemeriksa Keuangan UU BPK: "Kerugian Negara/Daerah adalah kekurangan uang, surat berharga dan barang yang nyata dan pasti jumlahnya sebagai akibat perbuatan melawan hukum baik sengaja maupun lalai."

Pasal 1 Angka 22 UU No. 1 Tahun 2004 Tentang Perbendaharaan Negara: "Kerugian Negara/Daerah adalah kekurangan uang, berharga, dan barang, yang nyata dan pasti jumlahnya akibat perbuatan melawan hukum baik sengaja maupun lalai."

Sedangkan Definisi keuangan negara menurut Undang-Undang 17 Tahun 2003 tentang keuangan negar pasal 1 angka 1 yang mengatakan: "Keuangan negara adalah semua hak dan kewajiban negara yang dapat dinilai dengan uang, serta segala sesuatu baik berupa uang maupun berupa barang yang dapat dijadikan milik negara berhubungan dengan pelaksanaan hak dan kewajiban tersebut.

Pengertian dan ruang lingkup keuangan negara dimana diterapkan pada pemahaman

10 Policy Paper Indonesian Corruption Watch, Penerapan Unsur Merugikan Negara dalam DelikTindakan Korupsi, ICW, 2014, hlm 17 
konsep "kerugian keuangan negara" dijelaskan pada penjelasan umum angka 3 Undang-Undang 17 Tahun 2003 adalah pada bagian tujuan, obyek dan peroses.

a. Pada sisi obyek pengertiannya Keuangan Negara memiliki ruang lingkup semua kewajiban dan hak negara dimana biasa dinilai dengan uang, antara lain kegiatan dan kebijakan dalam bidang moneter, fiskal dan pemberdayaan kekayaan negara yang dipisahkan, termasuk semua hal baik dalam bentuk uang, maupun juga barang yang bisa dijadikan kepunyaan negara terkait juga pelaksanaan kewajiban dan hak tersebut. Dari posisi subyek yang diartikan dengan Keuangan Negara mencangkup seluruh obyek yang sudah diterangkan di atas yang dipunyai negara, dan/atau dikuasai oleh Pemerintah Daerah, Pemerintah Pusat, Perusahaan Negara/Daerah atau badan lain yang ada berkaitan dengan keuangan negara.

b. Dari sisi proses, Keuangan Negara meliputi semua peroses kegiatan yang terkait dengan pendaya gunaan obyek seperti di atas mulai dari perumusan kebijakan dan pengambilan keputusan sampai dengan pertanggungjawaban.

c. Dari sisi tujuan, Keuangan Negara memiliki ruang lingkup semua kebijakan, kegiatan dan hubungan hukum yang terkait dengan pemilikan dan/atau penguasaan obyek seperti yang disampaikan di atas pada rangka penyelenggaraan pemerintahan negara.

Dari gambaran diatas kita telah melihat beberapa regulasi yang mengatur tentang "kerugian negara", "kerugian keuangan negara", dan "keuangan negara" dalam hal kerugian keuangan negara yang ada dalam UU Tipikor sendiri masih terbatas pemaknaanya maka bila mana pada UndangUndang isinya kurang jelas, menjadi tugas hakim agar dapat menafsirkan aturan tersebut suapaya dapat memutus suatu perkara secara cermat, berkeadilan dan sejalan dengan tujuan hukum, yaitu memberi kepastian Hukum. ${ }^{11}$

Hukum Pidana yang merupakan peraturan yang tertuang dalam tulisan-tulisan yang dibentuk, disusun dan diundangkan kemudian diterapkan. Hukum pidana itu sendiri terwujud melalui rangkayan kalimat (tertulis) ketika sudah dibentuk kemudian diterapkan dalam kehidupan nyata di dalam masyarakat menjadi hukum positif, dan akan menjadi efektif dan dirasakan mencapai keadilan dan kepastian hukum apabila penerapanya itu sesuai dengan yang dimaksud oleh pembentuk Undang-Undang mengenai apa yang ditulis dalam kalimat-kalimat itu. Dimana pertumbuhan masyarakat yang semakin berkembang, Kebutuhana akan keadilan

${ }^{11}$ C.S.T. Kansil, Pengantar Ilmu Hukum, Balai Pustaka, Jakarta, 1992, hlm 36 
dan hukum pun berubah perpadanan dengan nilai-nilai yang dipercaya oleh masyarakat, maka demi memberikan rasa keadilan dalam masyarakat yang berpadanan dengan nilai-nilai yang berkembangan dan dipercaya oleh masyarakat tersebut, maka pada teori dan fakta di lapangan hukum membutuhkan metode iterpertasi. ${ }^{12}$

Dalam memperluas makna "Kerugian Keuangan Negara" penulis menggunakan antara lain Tiga Penafsiran yaitu:

a. Penafsiran Historis

Penafsiran historis adalah Penafsiran pemaknaan undang-undnag sesuai dengan terbentuknya undang-undang dengan jalan melihat historis terbentunya sebuah undang-undang. Interpertasi historis memiliki ruang lingkup menafsirkan sesuai dengan historis peroduk hukum yang dibentuk. Undang-undang pasti bentuk reaksi dari kebutuhan sosial dan kepentingan masyarakat atau kebutuhan sosisal agar dapat menjadi suatu peraturan yang dapat di pahami secara historis. Suatu peraturan dapat dipandang sebagai suatu langkah dari pertumbuhan masyakata, yang artinya adalah diberikannya suatu penjelasan dengan menganalisa peroses sejarah terbentuknya suatu peroduk hukum tersebut. ${ }^{13}$ Yang perlu di perhatikan dari dibentuk

\footnotetext{
${ }^{12}$ Adami Chazawi, Pelajaran Hukum Pidana Bagian

2, RajaGrafindo Persada, Jakarta, 2016, hlm 3

13 Sudikno Mertokusumu, Penemuan Hukum, Liberty, Yogyakarta, 2009, hlm 60
}

UU Tipikor adalah tiga tujuan yaitu menangkap pelaku tipikor, pencegahan tipikor, dan pengembalian/pemulihan aset tipikor (asset recovery).

b. Penafsiran Sistematis

Penafsiran sistematis (systematische Interpretatie) merupan suatu bentuk penafsiran bertujuan untuk mencari makna dari norma hukum atau bagian/ unsur dari norma hukum dengan metode yang melihat suatu hubungan antara rumusan norma satu dan rumusan lainnya dari kacamata Undang-Undang. Kemudian menghubungkannya secara sistematis yang berarti dari susunansusunan norma tersebut apakah saling terikan dan memiliki hubungan satu sama lain. ${ }^{14}$ Dalam penjelasan UU tipikor di Alinea tiga yaitu "yang dimaksud dengan Keuangan negara adalah semua kekayaan negara dalam bentuk apapun, yang dipisahkan atau yang tidak dipisahkan, meliputi juga di dalamnya semua bagian kekayaan negara dan semua kewajiban dan hak yang timbul" tidak dijelaskan secara sepesifik apa itu kekeyaan negara yang dimaksud. Sedangkan penjelasan kekayaan negara menurut Direktorat Jendaral Kekayaan Negara (DJKN) membagi tiga subyek kekayaan negara antara lain: (1) Subyek kekayaan Negara yang dikuasai adalah

${ }^{14}$ Adami Chazawi, Op.Cit, hlm 7 
kekayaan Negara potensial yang dibagi dari sektor-sektor pertanian, agrarian/ pertanahan, pertambangan, kehutanan, mineral, dan minyak, batubara dan kelautan, gas bumi dan sumber daya air, perikanan, udara dan energi, antariksa, panas bumi, kekayaan Negara yang lain. dimuat dalam Undang-undang sektoral. Menteri keuangan sebagai pengelola fiscal dan menteri/pimpinan lembaga sebagai pengelola sektoral. (2) Subyek kekayaan Negara yang dimiliki adalah barang milik Negara/daerah yaitu barang tidak berwujud, barang berwujud, barang tidak bergerak, barang bergerak dari suatu perolehan atau pembeliaan atas beban APBN/D dan diperolehan lainnya secara sah. (3) Subyek kekayaan Negara yang dipisah berbentuk pemberian modal Negara pada BUMN/D, pemberian modal pemda pada BUMN/D, kekayaan Negara pada Badan Hukum lainnya, dan kekayaan Negara pada lembaga internasional.

Dalam penjelasan diatas telah ditemukan apa yang dimaksud kekayaan negara yaitu kekaayaan hayaiti dan non-hayati yang merupakan benda tidak berwujud dan berwujud, tidak bergerak maupun bergerak, yang dimiliki dan dikelola oleh negara. Subjek kekayaan negara ini kemudia dibagi 3 yang dimana dalam poin 1 di atas meliputi kekayaan lingkungan dan Sumber daya alam.

\section{c. Penafsiran Ekstensif}

Meberikan penafsiran yang memperluas makna dari kata-kata dalam peraturan ${ }^{15}$. Penafsiran ekstensif berarti berpengang pada peraturan yang telah ada. Dimana ada kalimat atau kata-kata yang kita berikan pengertian menurut makna sesuai dengan yang di pahami pada perkembangan masyarakat hari-hari ini, tidak hanya dimaknai dengar arti pada waktu peraturan tersebut dibuat. Bisa saja dimaknai dengan makna yang ada pada waktu peraturan tersebut dibentuk tapi kemudian makna tersebut diperluas dengan pemaknaan yang lebih sesuai dengang situasi sekaran yang bersandar secara obyektif pada pandangan masyarakat. ${ }^{16}$ Jelas penafsiran analogi dan penafsiran ekstensif berbeda walaupun sifatnya kurang lebih sama-sama memperluas makna, namun penafsiran analogi terlalu luas tidak lagi berpedoman pada norma, sedangkan penafsiran ekstensif masih berangkat dari norma. Dengan penafsiran ekstensif makna dari "kerugian keuangan negara" dapat di perluas yang tetap berangkat dari norma yaitu kerugian ekologis dapat dimaknai juga sebagai kerugian keuangan negara.

\footnotetext{
${ }^{15}$ C.S.T. Kansil, Op.Cit, hlm 39

16 Moeljatno, Asas-Asas Hukum Pidana, Rineka Cipta, Jakarta, 1993, hlm 27
} 
Setelah menggunakan metode interpetasi diatas maka ada 2 hal yang menjadi dasar kerusakan lingkungan dan biyaa perbaikan dapat di masukan sebagai kerugian keuangan negara yaitu: (a) Kerusakan ekologis tersebut harus disebabkan oleh Tindak pidana korupsi yang diataur dalam UU Tipikor; (b) Melihat sumber daya alam dan lingkungan hidup, keuangan negara, serta kekayaan negara menjadi satu kesatuan. Dengan demikian maka, lingkungan dan sumber daya alam harus dilihat sebagai kekayaan negara. Seperti yang penulis jelaskan dalam penafsiran sistematis di atas kekyaan negara adalah juga meliputi sumber daya alam. Dengan demikian suber daya alam adalah kekayaan negara yang jika di salah gunakan akan menimbulkan kerugian keuangan negara. ${ }^{17}$

\subsection{Pembuktian Kerugian Ekologis Demi Pemulihan Aset Tindak Pidana Korupsi}

Untuk melihat yang dimaksud dengan kerugian ekologis/lingkungan hidup yang perlu di perhatikan Pasal 90 (1) UndangUndang 39 tahun 2009 tentang Perlindungan dan Penglolaan Lingkungan Hidup mengatakan Instansi pemerintah dan pemerintah daerah yang diberi tanggujawab

17 Hariman Satria, Perluasan Makna Kerugian Keuangan Negara Dalam Korupsi Izin Usaha Pertambangan, Jurna Yudisial, vol.13 No.2 Agustus 2020, hlm 16 pada bidang lingkungan hidup memiliki kewenangan untuk menggugat dengan gugatan ganti rugi dan perbuatan tertentu terhadap usaha dan/atau kegiatan yang menyebabkan pencemaran dan/atau kerusakan lingkungan hidup yang mengakibatkan kerugian lingkungan hidup. Ayat 2 memaparkan bahwa lebih lanjut terkait kerugian lingkungan sebagai dimaksud dalam ayat (1) dirumuskan dengan Peraturan Menteri. Peraturan Menteri yang dimaksud adalah Peraturan Menteri Lingkungan Hidup (Permen LH) No. 17 Tahun 2014 tentang Kerugian Lingkungan Hidup Akibat Pencemaran Dan/atau Kerusakan.

Definisi kerugian ekologis/ lingkungan dalam permen tersebut ada dalam Pasal 1 (2) yaitu Kerugian Ekologis/ Lingkungan Hidup adalah kerugian yang mucul akibat pencemaran dan/atau kerusakan lingkungan hidup yang bukan merupakan hak milik privat. Ada dua hal yang perlu dipahami dalam dalam pasal 1 (2) yaitu: (a) Kerugian yang tibul karena suatu kerusakan lingkungan hidup atau pencemaran lingkungan hidup. Dalam hal kerugian ekologis dikenal dua metode untuk mnganalisanya yaitu jika pencemaran lingkungan diukur dengan Baku Mutu Lingkungan Hidup sedangkan jika terkait kerusakan lingkungan diukur menggunakan Keriteria Baku Kerusakan Lingkungan Hidup; (b) Bukan merupan lahan yang dimiliki Privat sedangkan lingkungan adalah milik dari pulik jadi 
bukan milik privat. Oleh karena itu dapat disimpulkan bahwa kerusakan atau pencemana lingkungan yang bukan milik privat akan menimbulkan kerugian lingkungan hidup. $^{18}$

Penghitungan kerugian akibat pencemaran dan atau kerusakan lingkungan hidup secara umum nilainya bersifat Ekstensif. Ekonomi Ekstensif merupakan nilai ekonomi berbasis ekosentrisme. Pandangan ekonomi ini mendobrak cara pandang ekonomi intensis berbasis antroposetrisme yang membatasi nilai ekonomi hanya untuk mencakup komunitas manusia dan kebutuhannya. Ekstensif ekonomi berbasis ekosetrisme akan mencangkup nilai tidak terbatas karena ekosisitem tidak dapat di ciptakan oleh manusia, sehingga jika terjadi kerusakan lingkungan pada ekosistem maka akan musna atau sulit untuk dipulihkan (irreversible).

Pemulihan ekosistem yang rusak itu hanya dapat dilakukan oleh Tuhan Pencipta Alam Semesta. Valuasi ekonomi ektensif umumnya bersifat minimalis dan limitative karena hanya keterbatasan pengetahuan manusia dalam menilai ekonomi ekosistem tersebut. Secara umum valuasi ekonomi lingkungan akibat kerusakan lingkungan mencangkup tiga komponen yaitu kerugian ekonomi, pemulihan lingkungan dan ke-

${ }^{18}$ Franky Butar Butar (Dkk), Op.Cit, hlm 4 rugian ekologis. ${ }^{19}$ Dalam hal kerugian lingkungan yang berhak menghitung adanya kerugian lingkungan menurut Pasal 4“Permen" LH 7"Tahun"2014 adalah ahli dalam valuasi ekonomi lingkungan hidup atau bidang Kerusakan dan/atau Pencemaran Lingkungan Hidup.

Berdasarkan perhitungan diatas dapat dihitung berapa yang menjadi kerugian keuangan negara yang timbul akibat rusaknya lingkungan. Dibebankannya kerugian tanah dan lingkungan kepada NA tentunya beralasan kuat yaitu menjadi gambaran bahwa keputusan NA memberi ijin eksplorasi tersebut ternyata berdampak luas tidak hanya pada finansial negara saja, tetap juga pada rusaknya lingkungan akibat pertambangan yang ijinnya diberikan secara melawan hukum. dibebankan kerugian ekologis tersebut jika di Analisa menggunakan ajaran kausalitas dalam hukum pidana adalah hal yang bisa menjadi jembatan dibebankanya kerugian keuangan negara pada NA.

Sebagaimana diketahui bahwa hubungan kausalitas akan selalu dijumpai pada saat ada kejadian dalam tingkah laku hidup hari demi hari yang adalah keseluruhan kehidupan manusia yang merupakan mahluk"sosial. Akan tetapi bentuk dari

\footnotetext{
${ }^{19}$ Basuki Wasis, Makalah Penghitungan Kerusakan Ekologis dari Daya Rusak Pertambangan Sebagai Kerugian Keuangan Negara, Departemen Silvikumum Fakultas Kehutanan, Institut Pertanian Bogor, Bogor, 2019, hlm 2
} 
hubungan kausalitas tersebut terkadang memunculkan persoalan yang kemudian menimbulkan ketidakpastian, oleh sebab itu maka bukan perkra yang gampang untuk menentukan kapan sesuatu perbuatan menjadi akibat dan kapan lalu perbuatan tersebut adalah merupakan sebab, apalagi jika dapat diketahui yang mana faktorfaktor rangkaian perbuataan yang menimbulkan akibat. ${ }^{20}$

Lebih lanjut berbicara tentang hubungan sebab akibat dalam hukum pidana maka kurang lebih ada empat teori, masingmasing:

\section{1) Teori Conditio Sine Qua Non}

Teori ini adalah teori mutlak yang menyampaikan dimana semua sebab dapat berkotribusi menimbulkan akibat. Pandangan ini dicetuskan oleh seorang bernama Von Buri yang adalah Ketua Mahkamah Agung Jerman. ${ }^{21}$

\section{2) Teori Generalisir}

Teori sebab akibat dari Von Buri dinilai sangat luas jika dipakai untuk menentukan pertanggungjawaban pidana, berdaskan hal itu teori tersebut kemudian banyak ditolak pada saat kemuculannya, karena teori tersebut dinggap teralu luas dan tanpa batasan yang jelas. Sebagai bentuk tanggapan dari

20 A.Z.Abidin, Andi Hamzah, Pengantar dalam Hukum Pidana Indonesia, Yarsif Watampone, Jakarta, 2010, hlm 213

21 Eddy O.S. Hiariej, Prinsip-Prinsip Hukum Pidana, Cahya Atma Pustaka, Yogyakarta, 2015, hlm 210 teori tersebut kemudian lahir teori Individualisir dan teori generalisir yang dimunculkan oleh Traeger yang kemudian dalam teori ini memberi batasan mana yang sebagai musabab dan mana yang sebagai syarat. Kemudian menarik suatu benang merah dari semua rangkaian tersebut yang mana yang merupakan sebab yang menimbulkan akibat yang dilarang. Teori Generalisasi memandang sebab in abstracto sesuai dengan perhitungan yang relevan yang pasti menghasilkan akibat. Pada teori ini juga ada didalamnya Teori adequat teori ini lahir dari seorang ahli matematika dari jerman yang namnya adalah J. Von Kries. $^{22}$

\section{3)Teori Individualisir}

Teori individualisir adalah teori yang mencari suatu kebenaran dimana hanya melihat dari satu faktor saja setalah perbuatan tersebut selesai dilakukan faktor yang dilihat adalah faktor yang paling berkotribusi atau berperan besar dalam menimbukan suatu akibat, faktor-faktor lainnya dipandang hanya merupakan faktor pendukung saja dan bukan lah sebuah faktor yang menimbulkan akibat. Penganut teori individualisir ini adalah dua orang yang 
bernama Birkmeyer dan Karl Binding. ${ }^{23}$

\section{4) Teori Objektif Nachtragliche Prognose}

Bahwa teori adequate Von Kries dan teori menggeneralisir lainnya, adalah merupakan ukuran dalam mencari ada atau tidak hubungan kausal teori ini dianggap tidak teralu obyektif, yang berarti ada tercampur sudut pandang subyektif (pengetahuan terdakwa). Maka dari itu pandangan ini dinamakan subyektif prognose (peramalan yang subyektif). Di sisi lain ada juga teori adequate yang memiliki pendirian atas sudut pandang obyektif, dimana hal ini dilakukan dengan mengingat situasisituasi setelah terjadinya suatu akibat. (obyektif nachtragliche prognose). Pandangan ini di pelopori oleh Van Hattum dan Rumeling. ${ }^{24}$

\section{5) Teori Relevansi}

Teori ini berpandangan bahwa tidak perlu mebedaan antara syarat dan musabab, yang sama dengan teori yang mengindividualisir dan menggeneralisir, melaikan diawali dengan menginterpretasi rumusan delik yang ada dalam aturan tersebut, dari suatu rumusan delik tersebut ketika diuraikan yang menjadi akibat yang dilarang kemudian dianalisa apa hal-hal yang dimaksud dalam aturan tersebut yang

\footnotetext{
${ }^{23}$ Adami Chazawi, Op.Cit, hlm 229

${ }^{24}$ Moeljatno, Op.cit hlm 110
}

menimbukan akibat yang dilarang. Sehingga dalam teori-teori yang mengindividualisir dan menggeneralisir yang menjadi persoalan adalah adakah hal-hal tersebut yang menjadi sebab yang kemudian memunculkan akibat yang dilarang? Maka teori relevansi menitik beratkan pada apa yang diatur di dalam rumusan delik terkait hal-hal yang menimbulkan akibat yang dilarang. $^{25}$

Dalam kasus di atas ajaran kausalitas yang tepat di terapkan adalah teori Individualis dari Birkmeyer dimana mencari satu sebab yang paling berkotribusi besar menimbulkan akibat sehingga beralasan Ketika kerugian ekologis lalu dibebankan kepada NA, dikarenakan NA adalah pejabat yang di beri kewenangan oleh Negara untuk mengluarkan ijin eksplorasi, dan ijin tersebut terbit secara melawan hukum, hal ini menjadi sebab yang paling besar berkotribusi menimbulkan akibat jika dilihat dari teori individualisir.

\section{KESIMPULAN}

Berdasarkan analisis permasalahan diatas penulis mengambil kesimpulan bahwa:

1. Korupsi di sektor sumber daya alam tidak saja merugikan finansial negara tetapi juga ada kerugian ekologis yang timbul, maka perlu melihat kerugian

${ }^{25} \mathrm{Ibid}, \mathrm{hlm} 113$ 
ekologis yang timbul akibat tindak pidana korupsi sebagai kerugian keuangan negara, karena pemahaman yang telah di bangun tentang perluasan makna kerugian keuangan negara menggunakan tiga metode interpretasi yaitu Ekstensif, Historis, Sistematis. Maka harus pula melihat kekayaan negara, keuangan negara sebagai satu kesatuan, yaitu kekayaan yang di dalamnya pula sumber daya alam, yang ketika disalah gunakan akan merugikan keuangan negara.

2. Dalam hal pembuktian adanya kerusakan atau pencemaran lingkungan dapat dihadirkan ahli dalam bidang tersebut yang ada dalam Permen LH 7 Tahun 2014 untuk menghitung kerugian lingkungan yang ditimbulkan akibat penerbitan ijin tambang secara melawan hukum.

\section{DAFTAR PUSTAKA}

\section{Buku}

Adami Chazawi, Pelajaran Hukum Pidana Bagian 2, RajaGrafindo Persada, Jakarta, 2016.

----------, Hukum Pidana Korupsi di Indonesia, Rajawali Pers, 2017.

A.Z. Abidin, Andi Hamzah, Pengantar dalam Hukum Pidana Indonesia, Yarsif Watampone, Jakarta, 2010.

Basuki Wasis, Makalah Penghitungan Kerusakan Ekologis dari Daya Rusak Pertambangan Sebagai Kerugian Keuangan Negara, Departemen Silvikumum Fakultas Kehutanan, Institut Pertanian Bogor, Bogor, 2019.

Bambabang Widjojanto Dkk, Penguasaan Sumber Daya Alam, Intrans Institute, Malang, 2017.

C.S.T. Kansil, Pengantar Ilmu Hukum, Balai Pustaka, Jakarta, 1992.

Daud Silalahi, Kristianto. Hukum Lingkungan dalam perkembangan di Indonesia. CV Keni Media, Bandung, 2015.

Eddy O.S. Hiariej, Prinsip-Prinsip Hukum Pidana, Cahya Atma Pustaka, Yogyakarta, 2015.

Kementerian ESDM, Geliatkan Nilai Tambah Sumber Daya Alam, NOMOR: 011.Pers/04/SJI/2020. 
Moeljatno, Asas-Asas Hukum Pidana, Rineka Cipta, Jakarta, 1993.

Marsel Selamat, Hukum Sumber Daya Alam Indonesia, Satara Press, Malang, 2018.

Peter Mahmud Marzuki, Penelitian Hukum, Predanamedia Group, Jakarta, 2005.

Policy Paper Indonesian Corruption Watch, Penerapan Unsur Merugikan Negara dalam Delik Tindakan Korupsi, ICW, 2014.

Sudikno Mertokusumu, Penemuan Hukum, Liberty, Yogyakarta, 2009.

\section{Peraturan Perundang-Undangan}

Undang-Undang Dasar Negara Republik Indonesia Tahun 1995

Undang-Undang Nomor 32 Tahun 2009 Tentang Perlindungan dan Pengelolaan Lingkungan Hidup

Undang-Undang Nomor 20 Tahun 2001 Tentang Perubahan Atas UndangUndang 31 Tahun 1999 tentang Pemberantasan Tindak Pidana Korupsi
Undang-Undang Nomor 1 Tahun 2004 Tentang Perbendaharaan Negara

Undang-Undang Nomor 15 Tahun 2006 Tentang Badan Pemeriksaan Keuangan Negara

Undang-Undang Nomor 17 Tahun 2003 Tentang Keuangan Negara

Peraturan Menteri Lingkungan Hidup Nomor 7 Tahun 2014 Tentang Kerugian Lingkungan Hidup Akibat Pencemaran Dan/atau Kerusakan

\section{Jurnal}

Hariman Satria, Perluasan Makna Kerugian Keuangan Negara Dalam Korupsi Izin Usaha Pertambangan, Jurna Yudisial, vol.13 No.2 Agustus 2020.

Franky Butar Butar (Dkk), Mungkinkah Kerugian Lingkungan Akibat Pertambangan dapat Dikategorikan sebagai Tindak Pidana Korupsi, Prosiding Tpp XXVIII Perhapi, 2019.

\section{Internet}

https://m.tempo.com/read/news/2016/02/22 /090747097/kpk-temuan-enamindikasi-tindak-pidana-di-sektorenergi. 


\section{BIODATA SINGKAT PENULIS}

Joey Josua Pamungkas Pattiwael

memperoleh Gelar Sarjana Hukum

pada Fakultas Hukum Universitas

Dr. Soetomo Surabaya Tahun 2019.

Pada saat ini sedang menempuh studi

Magister Hukum pada Fakultas

Hukum Universitas Airlangga

Surabaya. 